Available online at:

http://journal.unila.ac.id/index.php/tropicalsoil

DOI: $10.5400 /$ jts.2017.v22i1.21-28

\title{
Restoration of Soil Physical and Chemical Properties of Abandoned Tin- Mining in Bangka Belitung Islands
}

\author{
Ishak Yuarsah ${ }^{1}$, Etik Puji Handayani ${ }^{2}$, Rakhmiati $^{2}$ and Yatmin $^{2}$ \\ ${ }^{1}$ Indonesian Soil Reseach Institue JL.Tentara Pelajar No.12, Cimanggu Bogor, Indonesia. \\ ${ }^{2}$ Agricultural College Dharma Wacana Metro, Lampung, Indonesia, email: etikpuji68@gmail.com
}

Received 30 November 2016/ accepted 29 December 2016

\begin{abstract}
The practices of tin mining that remove all soil layers on top of the mineral deposit layers have caused serious environmental problems, i.e. degradation of soil physical and chemical properties and disappearance of vegetation, flora and fauna in ecosystems, which further can change the local microclimate. The tailing area of tin mining have unstable soil structure and low organic matter content, so it is vulnerable to land slides and erosion. The characteristics of the soils in the tailing area that are very acidic, low nutrient availability, low water holding capacity and high soil temperature challange the restoration and improvement processes of this area. The aim of the research was to develop appropriate restoration techniques to improve the soil properties of post tin mining land that have been degraded due to mining activities. Appropriate plant species and specific location technology were determined based on the characterization and evaluation of potential land resources. Annual crop cultivation, cultivation of legume cover crops (Mucuna sp., Calopogonium sp., Pueraria javanica) and management of top soil and organic matter should be applied in order to improve soil structure, maintain soil moisture, as well as to reduce nutrient loss in coarse sandy soils.
\end{abstract}

Keywords: Soil properties, restoration, tailing area, tin mining

\begin{abstract}
ABSTRAK
Praktek penambangan timah terbuka menyingkirkan seluruh lapisan tanah di atas deposit bahan galian menimbulkan masalah lingkungan yang cukup serius yakni: kerusakan sifat fisik dan kimia tanah, menghilangkn vegetasi, flora dan fauna pada ekosistem yang dapat merubah iklim mikro setempat. Pada areal tailing/bekas tambang memiliki struktur sangat tidak stabil, kandungan bahan organik sangat rendah sehingga rawan longsor dan erosi apabila ditimbun berbentuk bukit-bukit. $\mathrm{pH}$ tanah sangat masam sampai sangat masam, kandungan hara yang sangat rendah, daya menyimpan air rendah dan suhu tanah yang tinggi merupakan kendala yang dihadapi dalam upaya perbaikan sifat-sifat tanah bekas lahan tambang. Tujuan dari penelitian ini adalah untuk mencari teknologi konservasi dan cara perbaikan sifat-sifat tanah yang tepat pada lahan pasca penambangan timah akibat dari ulah manusia yang menyebabkan kerusakan lingkungan baik mikro maupun makro. Penentuan jenis tanaman dan teknologi spesifik lokasi dapat dilakukan berdasarkan karakterisasi dan evaluasi potensi sumberdaya lahan. Penanaman tanaman tahunan dan penanaman legume cover crop (Mucuna sp., Calopogonium sp., Peuraria javanica) dan pengelolaan tanah pucuk dan bahan organik merupakan suatu keharusan, selain untuk memperbaiki struktur tanah, memelihara kelembaban tanah, juga untuk mengurangi kehilangan hara, karena pada tanah-tanah yang bertekstur kasar (berpasir) hara dalam tanah mudah tercuci.
\end{abstract}

Kata Kunci: Area penambangan timah, karakteristik tanah, restorasi

\section{INTRODUCTION}

The restoration and improvement of post tin mining land within the area of production forest of Bangka Belitung Islands Province would be conducted by PT Tambang Timah. There are about

J Trop Soils, Vol. 22, No. 1, 2017: 21-28

ISSN 0852-257X
74 post tin mining areas covering 60,000 ha of land (Badan Pusat Statistik Kabupaten Belitung 2009) that need to be identified and restored, so that the data of land characteristics before and after exploitation of tin mining are needed. Spatial information on land resources, including location, distribution, potency, suitability and biophysical constraints of land before and after mining are needed in order to determine the restoration 
techniques that can accelerate the improvement of degraded land.

Mining is an activity that is conducted either manually or mechanically to extract minerals (SK Mentamben Number: 1211.K / 008 / M.PE- / 1995). Mining activities can be performed on the ground (open pit mining) and underground (deep mining) including excavation, dredging, and suctioning that cause the pile of hills and large pits filled with water. Pit can be defined as an ex-mining pool or mining land. The post mining land on the ground consist of holes or basins on the surface of land, which are filled with water and surface water runoff (rain, river, sea), resembling a large pond or lake. Environmental degradation is an action that results in a direct change to the physical and/or biological of the environment, resulting in an inefficient or nonfunctioning environment in supporting sustainable development (Law No. 4 of 1982).

The spatial information about land resources is needed to provide a direction for the planning and implementation of restoration of post tin mining land so that the environmental degradation can be mitigated and land productivity can be restored. In addition, appropriate plant species and locationspecific management techniques (i.e. soil fertility improvement and application of soil conservation techniques) should be determined and developed. Determination of plant species and location-specific technology is based on the characterization and evaluation of potential land resources to support the planning and implementation of restoration of post mining land so that the utilization of post mining land can be optimal and the environmental functions can be restored.

The ground mining process is conducted by excavation and spraying. Excavation is performed to peel materials over the tin deposit layers. The depth of peeled materials can reach $5 \mathrm{~m}$ to tens of meters below ground level, then the peeled materials are transported to the dumping area. The post mining activities will result in: (1) Pit (large pool), shallow or deep pit, filled with water or dry, (2) Dumping area is a pile of materials in the form of a mixture soil, rocks, sand, gravel or other materials, (3) Tailing is a pile of residual materials obtained from the separation process of tin from other materials through washing process. The residual materials can be sand, gravel and small stones.

Dumping area and tailing area can not be considered as land according to the scientific definition, because no soil development processes and pedogenic processes take place in the area. Both areas have a very low soil fertility due to: (a) the tailing materials have lost the soil colloids because of the spraying process during tin extraction; tin ores are separated from other materials using high pressure spraying so that the soil colloids are leached out; (b) at the dumping area there has been a reversal of soil layers due to the "cut and fill" processes. As a result, the bottom layer materials would be at the top layers, and have been mixed.

The research aimed to develop approriate restoration techniques to improve the soil properties of post tin mining land that have been degraded due to tin mining activities. In this case, appropriate plant species and location-specific technology would be determined based on the characterization and evaluation of potential land resources.

\section{MATERIALS AND METHODS}

\section{Study Area}

The study was conducted in the Province of Bangka Belitung Islands, located at the geographic coordinates of $01^{\circ} 30^{\prime}-03^{\circ} 45^{\prime}$ South Latitude and between $105^{\circ} 00^{\prime}-108^{\circ} 35^{\prime}$ East Greenwich Longitude. Specifically, the study sites are located at alluvial plain, which included alluvial valley, flow path, river terrace, and river embankment. In addition, the study sites are located at tectonic hills with the topography of convex terrain, undulating up to hilly.

\section{Methodology}

The study was conducted using a survey method. The disturbed soil samples were taken at $0-15 \mathrm{~cm}$ and $15-30 \mathrm{~cm}$ depth of soil profiles, which represent each unit of land. The undisturbed soil samples were taken using soil ring samplers with the diameter of $7.63 \mathrm{~cm}$ and height of $4 \mathrm{~cm}$.

The physical soil properties including bulk density, total porosity, pore distribution, and permeability were analyzed. The chemical soil properties such as $\mathrm{pH}$, organic matter content, the content of $\mathrm{N}, \mathrm{P}, \mathrm{K}, \mathrm{Ca}, \mathrm{Mg}, \mathrm{Na}$, and $\mathrm{Al}$, cation exchange capacity, and base saturation were analyzed as well.

\section{RESULTS AND DISCUSSION}

\section{Post-Mining Environmental Conditions}

The study area is located at various topography ranging from level (slope of $<3 \%$ ) up to hilly (slope of $25 \%$ ). Besides slope, other factors that affect the magnitude of erosion and soil degradation are soil type and rainfall. Most of the soils in this area belong to the order of Entisols, Inceptisols, Ultisols, 
and Oxisols, which are sensitive to erosion. The average rainfall in this area is $\pm 2,339 \mathrm{~mm}$ per year. The topography of the area, which is undulating up to hilly, is a factor that causes erosion and soil degradation. Mining activities always result in two opposite impacts i.e. as a source of prosperity and a potential environmental degradation.

The post-mining land should be restored into previous land uses, i.e. forests or plantations, according to the land suitability. The results of field observation showed that all prospective mining lands of PT Tambang Timah can be grouped based on the mining activities, namely: (1) the areas that have not been mined, (2) the areas that have been mined, but still occupied by unconventional miners for doing mining activities, and (3) abandoned mining areas.

There are 2 tin mining systems applied in Bangka Belitung Islands, i.e. spray mining and dredge mining. In the spray mining system, the tin mining process is divided into 3 stages: (1) Peeling: at this stage the dismantling of soil layers or rocks that do not contain tin ore can reach a certain depth. The peeled soil layers consist of: a) topsoil that has been weathered, which is a good medium for growing plants, and $b$ ) soil parent material that has not been weathered. (2) Spraying: this activity aims to dismantle or dissolve soils/ rocks containing tin ore, which further turns the soils/ rocks into mud. The mud containing tin ore then pumps into the washing installation (Figure 1). The spraying acitivities will leave holes (6-10 $\mathrm{m}$ depth) covering few hectares of land, and in the rainy season the post-mining holes will be filled with water. (3) Washing: this activity aims to separate tin ores from other materials. The separation process uses a gravitation technique in which the tin ore with a specific gravity of $7.2 \mathrm{~g} \mathrm{~cm}^{-3}$ will first be settled, followed by coarse sand (tailing) and gravel with a specific gravity of 2-4 $\mathrm{g} \mathrm{cm}^{-3}$, and then mud as the last material that would be settled. The washing process will produce tailing (with very low organic matter content, poor nutrients

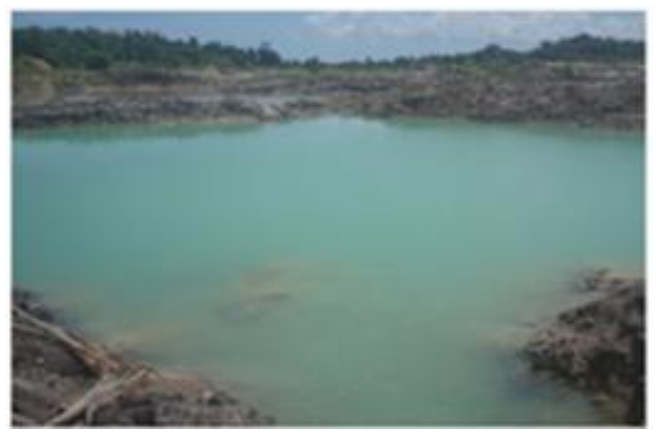

content, low water holding capacity), as well as saturated sludge. The tailings, which are present as small sand hills, contain sand $>90 \%$; dust $<8 \%$; clay $<0.5 \%$; organic-C $<0.10 \%$; cation exchange capacity (CEC) $<0.5 \mathrm{me} / 100 \mathrm{mg}$ (P4LHPuslittanak, 1996 and P4LH- Puslittanak 1999).

\section{Physical Properties of the Soils at Post Tin Mining Land}

The physical properties of the soils were studied in order to provide an optimum growing media for plants. The soil physical properties analyzed in the laboratory include: bulk density, particle density, permeability, pore size distribution, total porosity, drainage pores, available water pores, soil moisture content, and optimum soil moisture content for soil tillage (Husein et al. 2006; Agus et al. 2006).

Soil bulk density is one of the most common soil physical properties determined because it is closely related to the root penetration into the soil, soil drainage, and soil aeration. The results showed that the bulk density of topsoils is $1.51-2.60 \mathrm{~g} \mathrm{~cm}^{-3}$ with a total porosity ranging from $28.17 \%$ up to $35.67 \%$, and the aeration pores are $8.99-16.97 \%$ (relatively high) (Table 1). The high values of soil bulk density are due to the sandy soil texture and the low content of soil organic matter. The physical conditions of the soils need to be improved through soil tillage and soil organic matter management in order to create an optimum growing medium for plants. However, the management techniques of soil organic matter along with the location-specific balanced fertilization system should be determined and developed.

The movement of water in the soil can not be separated from the ability of the soil to hold water, which also depends on the arrangement of the soil particles, so that the excess water that can not be retained by the soil will move to the deeper soil layers. The movement of water in the soil is influenced by the soil properties such as texture, organic matter content, and compact/waterproof soil layers.

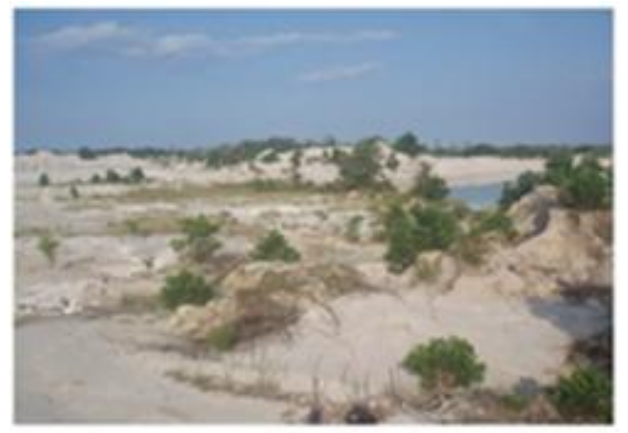

Figure 1. The condition of mining area performed using unconventional mining system. 
Table 1. Soil physical properties of post tin mining land in Bangka Belitung Islands.

\begin{tabular}{|c|c|c|c|c|c|c|c|c|}
\hline \multirow{3}{*}{$\begin{array}{l}\text { Location } \\
\text { /village }\end{array}$} & \multirow[b]{2}{*}{ Depth } & \multirow{2}{*}{$\begin{array}{c}\text { Bulk } \\
\text { Density }\end{array}$} & \multirow{2}{*}{$\begin{array}{l}\text { Particle } \\
\text { Density }\end{array}$} & \multirow{2}{*}{ Porosity } & \multicolumn{2}{|c|}{ Drainage pores } & \multirow{2}{*}{$\begin{array}{l}\text { Available } \\
\text { Water }\end{array}$} & \multirow{2}{*}{ Permeability } \\
\hline & & & & & Fast & Slow & & \\
\hline & $(\mathrm{cm})$ & \multicolumn{2}{|c|}{$\left(\mathrm{g} \mathrm{cm}^{-3}\right)$} & \multicolumn{4}{|c|}{ (\% vol.) } & $\left(\mathrm{cm} \mathrm{h}^{-1}\right)$ \\
\hline S.Pesak & $0-15$ & 1.58 & 2.28 & 30.86 & 15.65 & 6.21 & 4.46 & 9.77 \\
\hline Lasar & $0-15$ & 1.64 & 2.28 & 28.17 & 16.97 & 5.78 & 3.42 & 6.14 \\
\hline Sijuk & $0-15$ & 1.21 & 2.46 & 50.9 & 22.93 & 2.87 & 12.97 & 2.92 \\
\hline J.Asem & $0-15$ & 0.94 & 2.54 & 62.92 & 39.38 & 3.43 & 10.11 & 14.07 \\
\hline H.Makmur & $0-15$ & 1.15 & 2.61 & 56.04 & 28.78 & 3.09 & 9.99 & 8.68 \\
\hline Kelidang & $0-15$ & 0.90 & 2.38 & 62.22 & 23.69 & 3.91 & 18.75 & 5.5 \\
\hline Keretak & $0-15$ & 0.80 & 2.66 & 69.87 & 33.19 & 3.95 & 16.32 & 15.12 \\
\hline Lintang & $0-15$ & 1.07 & 2.62 & 59.2 & 23.69 & 3.91 & 14.16 & 14.07 \\
\hline Air Slumar & $0-15$ & 0.93 & 2.35 & 60.55 & 37.62 & 3.89 & 10.56 & 12.86 \\
\hline Mayang 1 & $0-30$ & 0.85 & 2.57 & 67.07 & 34.82 & 3.14 & 17.36 & 16.11 \\
\hline Tempilang.2 & $0-30$ & 0.85 & 2.60 & 67.38 & 59.19 & 2.77 & 2.97 & 6.14 \\
\hline S.Pesak & $0-30$ & 1.06 & 2.58 & 58.89 & 14.30 & 6.55 & 11.86 & 5.56 \\
\hline Lasar & $0-30$ & 1.24 & 2.57 & 51.74 & 18.38 & 3.9 & 4.07 & 1.48 \\
\hline Sijuk & $0-30$ & 1.56 & 2.44 & 35.89 & 17.74 & 3.06 & 5.46 & 9.36 \\
\hline J.Asem & $0-30$ & 1.08 & 2.58 & 58.09 & 31.4 & 3.92 & 9.68 & 6.98 \\
\hline H.Makmur & $0-30$ & 1.21 & 2.50 & 51.6 & 26.11 & 3.8 & 9.72 & 4.04 \\
\hline Kelidang & $0-30$ & 1.43 & 2.55 & 44.09 & 6.19 & 4.46 & 11.38 & 6.01 \\
\hline
\end{tabular}

Generally, the average permeability of the soils at the research site was moderate $\left(4.21 \mathrm{~cm}^{\text {hour }}{ }^{-1}\right)$ up to slightly fast $\left(9.77 \mathrm{~cm} \mathrm{hour}^{-1}\right)$. Appropriate soil tillage and soil organic matter management can improve the soil permeability.

\section{Chemical Properties of the Soils at Post Tin Mining Land}

The processes of unconventional tin mining resulted in sandy-textured tailings largely in the form of quartz sand, and deep pools. Quartz is a mineral that is hardly weathered, while the easily weathered sand fraction has been depleted, so it can be said that the soils in the post tin mining land are very poor of nutrients. The predominantly soil types are Udipsamment, Psammaquents, Udertent with the loose sand texture, and white-gray and white-brownish colors.

The sandy soils have low soil fertility as the soils are unable to hold nutrients, resulting in high loss of nutrients through leaching. In addition, the sandy soils have low CEC and low organic matter content. Plants often experience drought, especially in the dry season so they can not absorb nutrients, because the ability of sandy soils in holding water is very low. Due to the condition of the soils, the number of growing plants are very limited or in other words, only plants that have high adaptability to this extreme condition can survive, such as melastoma, kirinyuh (Chromolaena odorata), "rumput purun" (Lepironia articulata), acacia (Acacia mangium), "puspa" (Schima walichi Korth), and "karamunting" (Melastoma sp.). On the other hand, the predominant plants growing in the basins area that are influenced by seawater are mangrove plants, "gelam" (Melaleuca leucadendra), and Australia pines (Casuarina equisetifolia).

The chemical properties of the soils in the tailing area are presented in Table 2. The sand fraction in the tailings consisting of white, grayishbrown, brown and mixed sands is between $89 \%$ and $98 \%$. The field observation indicates that the sand at the tailing area is loose, in which such sand may not be able to bind water or nutrients for plant supply.

The soils in the tailings of post mining land are acidic with low organic-C content, low $\mathrm{N}, \mathrm{P}$, $\mathrm{K}, \mathrm{Ca}$, and $\mathrm{Mg}$ content, and low CEC level. Saturation of $\mathrm{Al}$ in the tailings ranges from $3 \%$ up to $56 \%$. Under such conditions, without improvement on the soil chemical properties, the tailings are not feasible for plant growth. This phenomenon is supported by the fact that most of the cultivated plants are not be able to grow on the tailing area.

\section{Restoration of Post-Mining Land}

The properties of the soils in the post-mining land include unstable soil structure, poor drainage 
Table 2. Soil chemical properties of post tin mining land in Bangka Belitung Islands.

\begin{tabular}{|c|c|c|c|c|c|c|c|c|c|c|c|c|c|c|}
\hline \multirow{3}{*}{$\begin{array}{l}\text { Location/ } \\
\text { village }\end{array}$} & \multirow[b]{3}{*}{ Sand } & \multirow[b]{2}{*}{$\mathrm{pH}$} & \multicolumn{2}{|c|}{$\begin{array}{l}\text { Organic } \\
\text { matter }\end{array}$} & \multicolumn{2}{|c|}{$\mathrm{HCl} 25 \%$} & \multirow{3}{*}{$\begin{array}{c}\mathrm{P} \\
\text { Bray } \\
\mathrm{P}_{2} \mathrm{O}_{5}\end{array}$} & \multicolumn{6}{|c|}{$\mathrm{NH}_{4} \mathrm{OAc} 1 \mathrm{~N}, \mathrm{pH} 7$} & \multirow{3}{*}{$\mathrm{Al}$} \\
\hline & & & & & & & & & & & & & Base & \\
\hline & & $\mathrm{H}_{2} \mathrm{O}$ & \multirow{2}{*}{\multicolumn{2}{|c|}{${ }^{\mathrm{C}}{ }^{\mathrm{N}} \mathrm{N}$}} & $\mathrm{P}_{2} \mathrm{O}_{5}$ & $\mathrm{~K}_{2} \mathrm{O}$ & & $\mathrm{Ca}$ & $\mathrm{Mg}$ & $\mathrm{K}$ & $\mathrm{Na}$ & CEC & saturation & \\
\hline & $\%$ & & & & \multicolumn{2}{|c|}{$\mathrm{mg} 100 \mathrm{~g}^{-1}$} & ppm & & \multicolumn{4}{|c|}{$\ldots \ldots . . \mathrm{cmol}(+) \mathrm{kg}^{-1} \ldots \ldots}$. & $\ldots \ldots \% \ldots$ & \\
\hline S.Pesak & 97 & 4.6 & 0.19 & 0.02 & 8 & 3 & - & 0.23 & 0.06 & 0.03 & 0.1 & 0.72 & - & 7 \\
\hline Lasar & 94 & 4.9 & 0.07 & 0.01 & 1 & 3 & 3.8 & 0.18 & 0.06 & 0.03 & 0.05 & 1.12 & 29 & 3 \\
\hline Sijuk & 91 & 4.4 & 0.73 & 0.07 & 5 & 3 & - & 0.23 & 0.06 & 0.03 & 0.05 & 2.8 & 13 & 56 \\
\hline J.Asem & 98 & 4.5 & 0.24 & 0.02 & 7 & 9 & 1.5 & 0.28 & 0.17 & 0.03 & 0.14 & 3.11 & 20 & 18 \\
\hline H.Makmur & 89 & 4.6 & 0.59 & 0.05 & 5 & 4 & - & 0.23 & 0.08 & 0.03 & 0.06 & 3.57 & 11 & 56 \\
\hline Kelidang & 94 & 4.8 & 0.09 & 0.01 & 1 & 6 & 6.2 & 0.09 & 0.012 & 0.03 & 0.05 & 1.78 & 16 & 10 \\
\hline Keretak & 82 & 4.3 & 0.38 & 0.03 & 1 & 6 & 5.1 & 0.18 & 0.12 & 0.03 & 0.05 & 3.24 & 12 & 54 \\
\hline Lintang & 93 & 4.5 & 0.51 & 0.05 & 3 & 3 & - & 0.05 & 0.05 & 0 & 0.02 & 2.9 & 4 & 56 \\
\hline Air slumar & 96 & 4.4 & 0.51 & 0.05 & 3 & 3 & - & 0.18 & 0.06 & 0 & 0.05 & 3.32 & 9 & 53 \\
\hline Mayang 1 & 95 & 4.6 & 0.15 & 0.01 & 2 & 3 & 4.9 & 0.14 & 0.06 & 0 & 0.05 & 1.93 & 13 & 56 \\
\hline Tempilang.2 & 91 & 4.8 & 0.4 & 0.03 & 3 & 3 & - & 0.14 & 0.06 & 0 & 0.07 & 2.24 & 12 & 29 \\
\hline
\end{tabular}

Description: $\mathrm{P}=$ tailing white, $\mathrm{C}=$ tailing chocolate, $\mathrm{K}=$ tailing greyishness, $\mathrm{Ca}=$ tailing $\operatorname{mix}$

and permeability, very low water holding capacity, highly acidic $\mathrm{pH}$, low organic matter content, and poor nutrients content. The low adaptability of some plant species in the extreme conditions of such soils affect the plant growth processes and mortality rates of the plants. To increase the amount of organic matter content in the soils of post-mining land, manure, mulching, and cultivation of land with legume cover crops can be applied (Sudjadi 1996). If the organic matter content in the soils is low, fertilization efficiency is also low. To increase the amount of organic matter content in the soils of post-mining land, the use of legume cover crops can be an option (Adiningsih and Sudjadi 1993)

Land restoration is aimed at improving the land quality in the dumping areas, tailings and pits to restore land productivity and/or environmental functions. The principles of post-mining land restoration are: (1) spatial arrangement and landforms, (2) management of topsoils, (3) improvements of mining land, and (4) dissemination of information. These activities should be simultaneously run. Arrangement of post mining land plays an important role in land restoration processes. Factors affecting the landforms in the post mining area are: (a) the volume of the mining materials transferred, (b) the increased volume of resettled mining materials, (c) the limited space of the area (d) the space of the land before being mined. The management of topsoils is crucial for the successful land restoration. The topsoils are used as a medium of growing plants with a thickness of $30-50 \mathrm{~cm}$, which are placed above the soil/tailing materials
(Sidik et al. 2006; Puslittanak 2007). The previous experiment showed that without topsoil layers, it is difficult to plant the post-mining land during the first 2 to 3 years. The topsoils consist of: top soils and sub soils, and even the weathered soil parent materials. The chemical, physical, and biological properties of topsoils are much better than the tailings. Therefore, the separation of topsoils from subsoils and placement of topsoils in a safe area are necessary during the early stage of mining process. At the beginning of mining process, collecting the topsoils is less problematic. However, at the end of the mining process, collecting the topsoils are getting harder. This is due to: (1) some of the topsoils are buried under the tailings, and (2) the land surfaces that need to be covered by the topsoils are very large. If the ex-mining land is not possible to be covered by the topsoils, the land surface would be covered by the non-toxic mining materials.

The restoration of post-mining land can be done by applying organic materials, lime, dolomite, phosphate-rock, zeolite, steel slag, and/or bitumen. The types of organic matter that can be used are manure, green manure, residual crops, sawmill waste and others. Green manure can be made using legume cover crops, grasses, trees or other shrubs (Puslittanak 2007).

\section{Selection of Plant Types for Land Restoration}

Tree is the selected plant type that can be grown on the post-tin mining land since the tree can grow 
Table 3. Dosage of inorganic fertilizers applied for cashew plants (LPTP Koya Barat, 2014).

\begin{tabular}{lccc}
\hline \multirow{2}{*}{ Plant age } & \multicolumn{3}{c}{ Type and dosage of inorganic fertilizer $\left(\mathrm{g} \mathrm{tree}^{-1}\right.$ year $\left.^{-1}\right)$} \\
\cline { 2 - 4 } & Urea & SP-36 & $\mathrm{KCl}$ \\
\hline 1 Year & 40 & 25 & 20 \\
2 years & 100 & 50 & 40 \\
3 years & 160 & 100 & 80 \\
4 years & 200 & 200 & 160 \\
5 years & 500 & 375 & 300 \\
\hline
\end{tabular}

well in eroded soils, rocky soils and alluvial soils with low $\mathrm{pH}$ (4.2). In addition, the tree is able to adapt to the poor soil conditions, and has a good economic values for wood industry and feed. The types of tree that are potential to be grown on the post-mining land are acacia (Acacia mangium), "puspa” (Schima walichi Korth), teak (Tectona grandis Linn F.), "simpur" (Dillenia suffruticosa Griff. ex Hook), "sungkai" (Peronema canescens), "sengon laut" (Albazia falcata), "gelam" (Melaleuca leucadendra), cashew tree (Anacardium occidentale) and "tusam" (Pinus merkusii). The types of plants mentioned above can grow on various soil types, in the area with the elevation of $30-130 \mathrm{~m}$ above sea level, rainfall between 1,000 $\mathrm{mm}-4,500 \mathrm{~mm}$ per year, the climate types of A up to $\mathrm{C}$ according to the classification proposed by Schmidt and Ferguson (1951) and the optimum temperature of

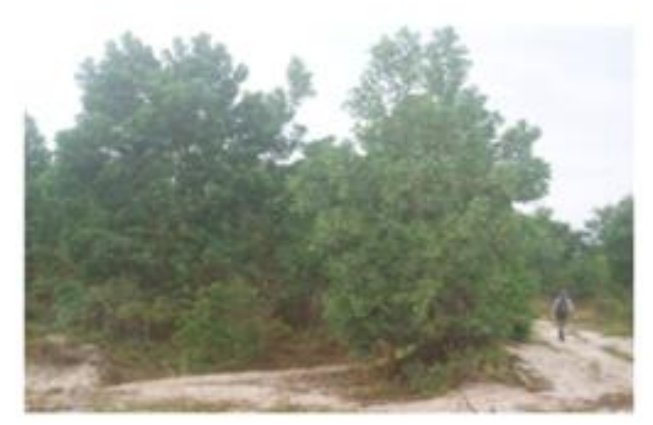

$32-42^{\circ} \mathrm{C}$. Sungkai trees (Peronema canescens) generally grow in the wetland of secondary forests and sometimes in the dryland of secondary forest, but they can not be found in the primary forests and periodically flooded areas (Irwanto 2007).

The cultivation of legume cover crop (LCC) aims to cover the soil surface with the plant quickly, to increase soil organic matter content since the LCC is a good source of organic matter, and to suppress erosion and surface run off. The selected LCC types are capable to adapt well to poor soil chemical and physical conditions. The LCC types that are commonly cultivated are Centrosema pubescens (CP), Pueraria javanica (PJ), or Calopogonium mucunoides (CM).

Implementation of the restoration measures for the improvement of post-mining land should use existing local plants around the mining sites such as

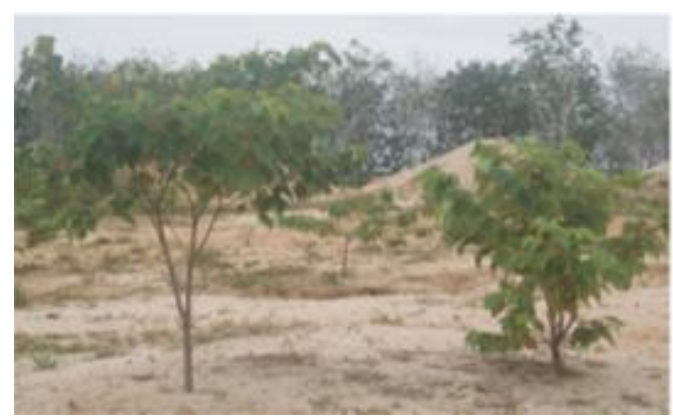

Figure 2. Hibiscus tiliaceus and Acacia mangium as pioneer plants growing on post mining land.
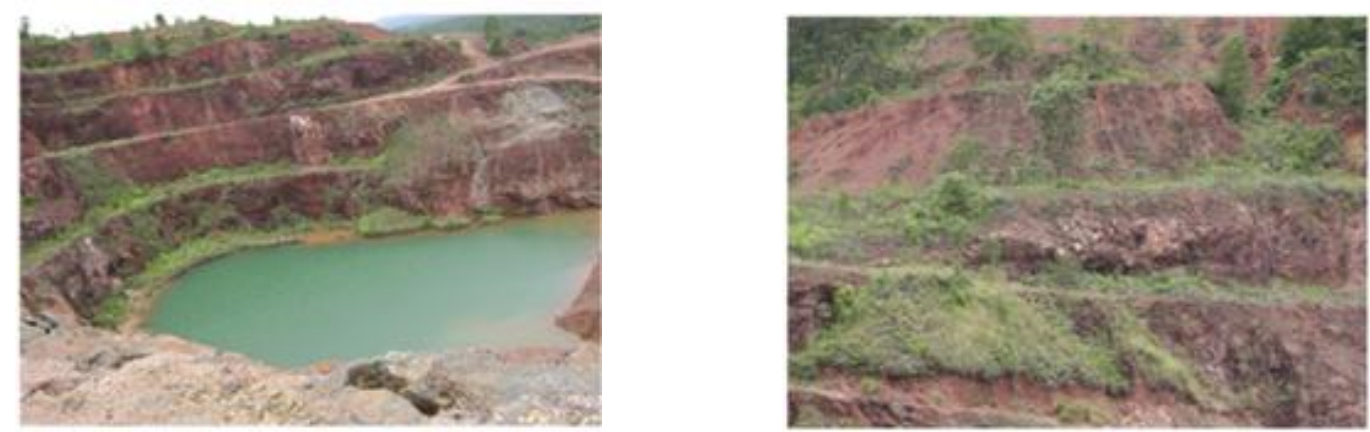

Figure 3. Restoration on hill-shaped tailings containing of mainly sand fraction. 
"mentangor" (Calophyllum insularum), melastoma, "mentru" (Schima walichi), "puspa" (Schima walichi Korth), mangrove plants and others, while the acacia (Acacia mangium) is suitable for each location or for all types of land both fertile and critical mining lands as an introductory plant. The existing introductory plants growing on the post mining area are cashew tree (Anacardium occidentale), mahoni (Switenia mucrobhyla), albizia (Albazia falcata), which are planted in a pot system as found in Bandul Experimental Station in Mentok, Indonesia. All of these plants should be prepared in large quantities. The dosages of fertilizers applied to the restored land are presented in Table 3.

Planting acacia (Acacia mangium), mahogany (Switenia mahagoni), "sengon laut" (Albazia falcata), and coconut tree (Cocos nucifera) can be conducted with a pot system of $60 \mathrm{~cm} \times 60 \mathrm{~cm} \times$ $50 \mathrm{~cm}$, with a planting distance of $4 \mathrm{~m} \times 4 \mathrm{~m}$. The medium used to fill in the planting holes is soil mixed with gravel or subsoil of Ultisols. Up to 6 months after planting, the plants can grow well, however, the plants may experience nutrient deficiencies with the increase of plant age as the soil type outside the planting holes is a sandy soil (Figure 2).

\section{CONCLUSIONS}

The fertility status of the soils in the mining land is generally low to very low. This condition is due to the characteristics of the soil parent materials that are poor in mineral reserves, coupled with the intensive leaching of nutrients, so the soils are poor in nutrients especially $\mathrm{N}, \mathrm{P}, \mathrm{K}$, organic-C and exchangeable cations.

The restoration of the soils/planting media in the post tin mining land in the Province of Bangka Belitung Islands can include, among others, improvement of $\mathrm{pH}$ by liming, application of organic fertilizers to increase soil organic-C content, application of zeolite amides, and N, P, K fertilizers according to the needs of plants grown on the restored lands.

Annual crops or green plants that can be cultivated at post-mining land include local plants (Acasia mangium, Albizia falcata, Switenia mahagoni, Leucaena leucocephala, Gliricidia sp., Gmelina arborea, Ceiba pentandra, Pterocarpus indicus, Aleurites moluccanus), as well as fruit plants, such as cashew (Anacardium occidentale) breadfruit (Artocarpus altilis), durian (Durio zibethinus), "duku" (Lansium parasiticum), "langsat" (Lansium domesticum), rambutan (Nephelium lappaceum)), whereas the cover crops that can be used for land restoration and erosion prevention are LCC (Mucuna sp., Centrosema pubescens, Pueraria javanica, Calopogonium mucunoides), and Grasses (Vetiveria zizanioides, Paspalum sp., Brachiaria decumbens, Panicum maximum).

\section{REFERENCES}

Anonymous. 2003. Laporan Dinas Pertanian dan Kehutanan Provinsi Kepulauan Bangka Belitung. Badan Pusat Statistik Kepulauan Bangka Belitung (in Indonesian).

Adiningsih S and M Sudjadi. 1993. Peranan sistem bertanam lorong (alley cropping) dalam meningkatkan kesuburan tanah pada lahan kering masam. Hal 30-40 dalam Risalah Seminar Hasil Penelitian Tanah dan Agroklimat, Puslittanak, Bogor. (in Indonesian).

Agus F, RD Yustika and U Haryati. 2006. Determination of the volume of soil in the Physical Properties of Land and its Analytical Method. Center for Agricultural Land Resources Research, Agricultural Research and Development Agency, Ministry of Agriculture.

Badan Pusat Statistik Kabupaten Bangka, 2009. Bangka Selatan Dalam Angka 2009 (in Indonesian).

Katalog BPS 1403. 1904. Kerjasama Badan Perencanaan Pembangunan Daerah Kabupaten Bangka Selatan dengan Badan Pusat Statistik Kabupaten Bangka 2009. Nomor Publikasi: 1901.04.02. pp. 223 (in Indonesian).

Badan Pusat Statistik Kabupaten Belitung Timur. 2009. Belitung Timur Dalam Angka. Katalog BPS: 1403. 1906. pp. 379 (in Indonesian).

Badan Pusat Statistik Kabupaten Belitung. 2009. Belitung Dalam Angka. Katalog BPS: 1403.1902. ISSN: 0215.4005. pp. 295 (in Indonesian).

Conwey GR. 1987. Rapid Rural Appraisal and Agroecosystem Analysis: A Case Study from Northern Pakistan. Proceeding of the 1985 Interational Conference on RRA. Rural System Res. And Farming System Res. Project. Khon Kaen, Thailand.

Husein S, A Rachman and Sutono. 2009. Indicators for natural land sampling Soil Physical Properties and Analytical Methods. R \& D Center for Agricultural Land Resources, Agency for Agricultural Research and Development, Department of Agriculture.

Irwanto. 2007. Budidaya tanaman kehutanan. Yogyakarta. http://www.irwantoshut.com.

Loka Pengkajian Teknologi Pertanian, Koya Barat, Irian Jaya (LPTP). 1997. Pemupukan tanaman jambu mete. Lembar Informasi Pertanian, No. 163/97.

Puslittanak_P4LH. 2009. Laporan akhir penelitian studi upaya rehabilitasi lingkungan penambangan timah. Kerja sama Puslittanak dengan Proyek Penataan Lingkungan Hidup. (Tidak dipublikasikan).

Puslittanak. 2007. Laporan Akhir Pengujian dan Pengembangan Reklamasi Sumberdaya Lahan serta Pelatihan Tahun III. Kerja Sama PTBA dengan Pusat Penelitian Tanah dan Agroklimat Bogor. (Tidak dipublikasikan). 
Ricards LA and LA Fireman. 1943. Pressure plate apparatus for measuring misturesorption and transmission by Soils. Soil Sci 56: 395-404.

Ricards LA. 1947. Preassure membrane apparatus, construction and use. Agric Eng 28:451 454.

Sudjadi M. 1996. Reklamasi dan reboisasi lahan bekas tambang, Makalah disajikan pada pertemuan teknis pengelolaan lingkungan Departemen Pertambangan dan Energi 1995/1996. Dirjen Reboisasi dan Rehabilitasi Lahan, Dephut.
Schmidt FH and JHA Ferguson. 1951. Rainfall Type Based on Wet and Dry Period Ratios for Indonesia with Western New Guinea. Verh. No.42. Jawatan Met. dan Geofisik, Jakarta.

Sidik H, Tala'ohu, S Sukmana, D Erfandi and D Sudjarwadi. 2006. Reklamasi tanah pasca penambangan sisa galian penambangan batu bara dan monitoring erosi di Tanjung Enim. Kerja Sama PTBAdengan Pusat Penelitian Tanah dan Agroklimat Bogor. Prosiding Pembahasan Penelitian Tanah dan Agroklimat, Bidang Fisika, Knservasi Tanah dan Air dan agroklimat. Bogor, 21-23 Agustus 1996. Pusat Penelitian Tanah dan Agroklimat, Bogor 